\title{
Correlations between malocclusion and anomalies in the posture
}

\author{
M. Milkov, M. Stoykov \\ Faculty of Dental medicine, Medical University - Varna
}

\begin{abstract}
:
Posture is understood as the relative position of various body segments in relation to each other and relative to the environment. Postural control is characterized by the ability to adapt our use of sensory information to changing tasks and environmental conditions. Malocclusion and incorrect body posture are two very common issues in growing subjects and especially in patients with mixed dentition, where it is still possible to intervene to modify and correct both conditions. In order to perform a correct diagnosis and an orthodontic treatment plan, the relationships between occlusion and posture should be evaluated to establish the most appropriate strategy of treatment and an interdisciplinary approach between different healthcare professionals. The aim of this study is to investigate the possible relationship between malocclusion and body posture anomalies.
\end{abstract}

Key words: malocclusion, posture, balance

\section{Introduction}

Posture is understood as the relative position of various body segments in relation to each other and relative to the environment. Thus, humans can take an infinite number of positions during daily and sport activities, such as standing, walking, running, throwing an object, etc. The posture in which both feet are in contact with the ground indicates the position commonly known as bipedal upright posture. The control of posture is essential for successfully achieving motor actions and implies the control of body position in space, with the double purpose of orientation and stability. $(9,12)$ Postural orientation involves proper positioning of the body segments relative to each other and to the environment. Stability during quiet standing involves the maintenance of the center of mass projection within the boundaries of the base of support.

Posture control is characterized by the ability to adapt our use of sensory information to changing tasks and environmental conditions. This process involves determining the accuracy of incoming sensory inputs and selecting the most appropriate sense for the context and changing the relative weighting of sensory inputs for postural control depending on their accuracy for orientation. (22)

Several factors may modify body posture and balance, among these dental malocclusion has great relevance. (17) Analyzing the occlusion can identify if the individual has physiological or pathologi- 
cal relationship between the dental arches, which is also known as malocclusion. (13)

Aim: The aim of this study is to investigate if there is a connection between malocclusion and body postural anomalies.

\section{Material and methods}

The following scientific databases were included for the study: MEDLINE, Scopus, EMBASE and PubMed, with a time period from 1989 to 2020. For the search the keywords - malocclusion, posture and balance were used.

\section{Results and discussion}

Malocclusion and incorrect body posture are two common issues in growing subjects and especially in patients with mixed dentition. In the specified period it is still possible to intervene to modify and correct both conditions. In order to perform a correct diagnosis and an orthodontic treatment plan, relationships between occlusion and posture should be evaluated. This is done in order to establish the most appropriate strategy of treatment and an interdisciplinary approach between different healthcare professionals. (6)

Malocclusion can be defined as an imbalance between the masticatory system and neuromuscular temporomandibular joint. It is considered as a result of the sum of genetic, environmental and postural elements therefore of multifactorial origin. (18) Deformations in occlusion can occur in the three anatomical planes. Paying attention to the sagittal plane, three occlusion classes are found. The first, Class I, is the physiological relationship between the teeth, where the mesiobuccal cusp of the maxillary first molar occludes with the buccal groove of the mandibular first molar (normoclusion). The Class II or overshot, occurs when the mesiobuccal cusp of the maxillary first molar occludes anterior to the buccal groove of the mandibular first molar. Class II malocclusion can be further subdivided into two types, differing by the position of incisors. In class II, division 1 cases maxillary incisors are tilted outwards which creates significant overjet and deep bite occlusion. In class II, division 2 maxillary lateral incisors are tilted labially. Finally, in class III cases, mesiobuccal cusp of the maxillary first molar occludes posterior to the buccal groove of the mandibular first molar. (4)

Many other types of malocclusion are found in the literature, for instance, the posterior crossbite consisting of an abnormal relationship in the lateral direction of one or more teeth of the maxillary, mandibular, or both, resulting in a disability performing the normal occlusion and open bite where there is a lack of contact between the incisors. (2)

For the period 1989-2020, 189 review and 1739 research articles were published. Results from some of the studies are presented in Table 1.

Tabl. 1. Studies and main results.

\begin{tabular}{|c|c|l|c|l|}
\hline Year & Authors & Objective & Population & Main results \\
\hline 2010 & $\begin{array}{c}\text { Perinetti et } \\
\text { al. [17] }\end{array}$ & $\begin{array}{l}\text { To investigate whether malocclusion } \\
\text { is related to postural changes in } \\
\text { young people. }\end{array}$ & 122 & $\begin{array}{l}\text { Few data were considered significant, } \\
\text { including the primary phase of teeth and } \\
\text { malocclusion classified as overbite shown } \\
\text { to be associated with the center of gravity } \\
\text { changes measured by the pressure pad. }\end{array}$ \\
\hline 2011 & $\begin{array}{c}\text { Aldana et } \\
\text { al. [1] }\end{array}$ & $\begin{array}{l}\text { To test the null hypothesis: } \\
\text { "there is no relationship between } \\
\text { malocclusion and postural changes } \\
\text { of head and neck." }\end{array}$ & 116 & $\begin{array}{l}\text { Among the results were found associations } \\
\text { between anti-clockwise rotation skull with } \\
\text { Class III mandibular posterior rotation with } \\
\text { dolichofacial individuals and Class II with the } \\
\text { tongue position at rest. }\end{array}$ \\
\hline 2011 & $\begin{array}{c}\text { Perillo et } \\
\text { al. [16] }\end{array}$ & $\begin{array}{l}\text { To investigate the relationship } \\
\text { between malocclusion and Helkimo } \\
\text { Index } \geq 5 \text { with postural changes in } \\
\text { children and young people. }\end{array}$ & 1178 & $\begin{array}{l}\text { The correlation between patients with } \\
\text { malocclusion and Helkimo Index } \geq 5 \text { with } \\
\text { the worst asymmetry trunk and better } \\
\text { performance in the Fukuda test was found. }\end{array}$ \\
\hline 2012 & $\begin{array}{c}\text { Deda et } \\
\text { al. [5] }\end{array}$ & $\begin{array}{l}\text { Comparing a group of patients with } \\
\text { malocclusion with a control group } \\
\text { and investigate whether there are } \\
\text { differences between head posture. }\end{array}$ & 25 & $\begin{array}{l}\text { Regarding the evaluation by photogrammetry, } \\
\text { there was no significant difference between } \\
\text { groups. Clinical inspection has achieved } \\
\text { significant results, where 100\% of Class II } \\
\text { subjects had forward head and 73.3\% in the } \\
\text { control group, showed neutral head position. }\end{array}$ \\
\hline
\end{tabular}




\begin{tabular}{|c|c|c|c|c|}
\hline 2013 & $\begin{array}{l}\text { Silvestrini- } \\
\text { Biavati et } \\
\text { al. [20] }\end{array}$ & $\begin{array}{l}\text { To investigate the incidence } \\
\text { of malocclusion with ocular } \\
\text { convergence and postural } \\
\text { disorders. }\end{array}$ & 605 & $\begin{array}{l}93.8 \text { to } 94.2 \% \text { of the entire sample, consisting } \\
\text { of individuals with and without malocclusion } \\
\text { presented symmetry of the lower limbs. For } \\
\text { gait disturbance, no significant differences } \\
\text { were found between the occlusal classes. }\end{array}$ \\
\hline 2014 & $\begin{array}{c}\text { Park et al. } \\
{[14]}\end{array}$ & $\begin{array}{l}\text { To investigate the prevalence } \\
\text { of nasal septal deviation and } \\
\text { concha bullosa among patients } \\
\text { with malocclusion as common } \\
\text { anatomical variations that can } \\
\text { affect nasotracheal intubation in } \\
\text { comparision with previous studies. }\end{array}$ & 634 & $\begin{array}{l}\text { Septal deviation was found in } 402 \text { patients } \\
(63.4 \%) \text {. Concha bullosa was found in } 328 \\
\text { patients }(51.7 \%) \text {. Both of them were found } \\
\text { in } 238 \text { patients. Three hundred twenty-five } \\
\text { patients had the middle concha bullosa, } \\
\text { sorted by type into true (182), lamella ( } 80) \\
\text { and bulbous type (33), while for } 30 \text { patients, } \\
\text { combination of two or more types were } \\
\text { observed. That more closely preoperative } \\
\text { evaluation is necessary for patients with } \\
\text { malocclusion planning on surgery using } \\
\text { nasotracheal intubation. }\end{array}$ \\
\hline 2016 & $\begin{array}{l}\text { Lopatienè } \\
\text { et al. [11] }\end{array}$ & $\begin{array}{l}\text { To evaluate the relationships } \\
\text { between hard and soft tissues } \\
\text { and upper airway morphology } \\
\text { in patients with normal sagittal } \\
\text { occlusion and Angle Class II } \\
\text { malocclusion according to gender. }\end{array}$ & 114 & $\begin{array}{l}\text { Cephalometric analysis applied in our study } \\
\text { showed that Angle Class II patients with } \\
\text { significantly decreased facial convexity angle, } \\
\text { increased nasomental, upper lip-chin, and } \\
\text { lower lip-chin angles, and upper and lower } \\
\text { lips located more proximally to the E line } \\
\text { more frequently had constricted airways. }\end{array}$ \\
\hline 2018 & $\begin{array}{l}\text { Yogi et al. } \\
\text { [23] }\end{array}$ & $\begin{array}{l}\text { To evaluate a possible association } \\
\text { between overall functional } \\
\text { impairment and malocclusion in this } \\
\text { population }\end{array}$ & 70 & $\begin{array}{l}\text { The results showed that the type of Cerebral } \\
\text { palsy, the degree of motor involvement, and } \\
\text { the presence of parafunctions are important } \\
\text { factors to be considered to establish a correct } \\
\text { diagnosis of malocclusion in persons with } \\
\text { Cerebral palsy. }\end{array}$ \\
\hline
\end{tabular}

Several studies have examined the correlation between malocclusion and parameters of body posture in the sagittal and frontal planes. Results identified a connection between structural orthopaedic diseases and occlusal morphology. $(9,10)$

Segatto et al. found that children with various spinal deformities have a high number of malocclusions (19), and Ben-Bassat et al. proved that patients with idiopathic scoliosis showed more asymmetric features characteristic of malocclusion than a random control group. (3) Moreover, children with congenital hip dislocation are more predisposed to the development of a lateral cross-bite. (7) However, the results from studies looking at the correlation between poor body posture and dental occlusion are conflicting.

Sinko et al. compared body posture in 29 Class II and Class III patients, and found that the apex of the thoracic kyphosis was more cranial in Class III patients than in Class II patients or healthy controls. (21)

Based on these, it is observed that only the orthodontic treatment is not sufficient for the correction of postural dysfunctions possibly generated by mal- occlusion. Perez et al. (15) suggests that other factors may be associated with postural changes (such as age, the type of teeth and others), and sometimes overlaps a malocclusion.

This review also includes two studies that used body balance in their methods. The first, of Perinetti et al. (17), aimed to investigate whether malocclusion was correlated with postural changes in young individuals, and it used a sample of 122 young people, between 10 and 16 years with malocclusions. The anteroposterior and lateral deviations have been verified by pressure platform on two conditions: mandibular relaxation and dental intercuspation. Few data were considered significant, including malocclusion classified as overbite shown to be associated with anteroposterior and lateral changes the center of gravity body. However, significant variables considered corresponded to $3-9 \%$ of the evaluation carried out, not being sufficient, according to the authors, to attest to the modification of postural stability.

In the second study Perillo et al. (16) assessed body balance, investigating the relationship between malocclusion and Helkimo Index $\geq 5$ with postural changes in 1178 young people from 11 to 19 years. 
Posture was analyzed by static evaluation (tilt and trunk asymmetry) and dynamic (Test of Fukuda steps, validated for balance assessment). A significant correlation was found between patients with malocclusion and Helkimo Index $\geq 5$ - worse asymmetry trunk and better performance in the Fukuda test. These results show that individuals with malocclusion can develop a change of static equilibrium, but not significant when evaluated dynamically. Perillo et al. (16) also assume that the greater activation of postural muscles in these individuals may have positively influenced the Fukuda test, increasing their performance.

Aldana et al. (1), through a cross-sectional study, sought the relationship between malocclusion and postural abnormalities of the head and neck. For this, they used a sample of

116 malocclusion patients who have undergone orthodontic treatment. Thus sought associations between craniocervical Rocabado analysis, the cephalogram and functional evaluation of the language. Weak associations were found between the counterclockwise rotation skull with Class III, the mandibular posterior rotation and dolichofacial and facial individuals and Class II with the tongue position at rest.

Deda et al. (5) in their study, compared the position of the head in different classes (Class I, II and III) by photogrammetry and clinical inspection the sample of twenty-five patients diagnosed with malocclusion. There was no significant difference between classes and influenced malocclusion on the angle head-neck evaluated by photogrammetry. However by clinical inspection, he noticed a pattern in head position in individuals Class II, where $100 \%$ had forward head. Another significant value was observed in the control group, who did not have changes in occlusion, where $73.3 \%$ had neutral head position.

Silvestrini et-Biavati al. (20) analyzed the incidence of malocclusion correlating with posture and disorders of ocular convergence. In a sample of 605 children, they found that 93.8 to $94.2 \%$ of the entire sample, consisting of individuals with and without malocclusion presented symmetry of the lower limbs. The study also evaluated the presence of gait disturbance, without any significant differences between the occlusal Classes.

\section{Conclusion}

Further research could help to reveal more details on the correlations between body posture and malocclusions from a pathogenic and clinical point of view. Scientists doubt whether the diseases occur simultaneously or they are dependent on the each other. It is not known for sure as well if one of the two is treated, there would be an influence on the other.

\section{References:}

1. Aldana PA, Báez RJ, Sandoval CC, Vergara NC, Cauvl LD, Reguera AF. Asociación entre maloclusiones y posición de la cabeza y cuello. Int. J. Odontostomat. 2011;5(2):119-25

2. Artese A, Drummond S, Nascimento JM, Artese F. Critérios para o diagnóstico e tratamento estável da mordida aberta anterior. Dental Press J Orthod. 2011 Mai-Jun;16(3):136-61

3. Ben-Bassat Y, Yitschaky M, Kaplan L, Brin I: Occlusal patterns in patients with Idiopathic scoliosis. Am J Orthod Dentofacial Orthop, 2006; 130: 629-33

4. Bricot B. Posturologia. 2a Ed. São Paulo: Ícone; 2001

5. Deda MRC, Mello-Filho FV, Xavier SP, Trawitzki LVV. Postura de cabeça nas deformidades dentofaciais Classe II e Classe III. Rev. CEFAC. 2012 Mar-Abr;14(2):274-80

6. Grassi, F.; Pazzaglia, U.; Pilato, G.; Zatti, G. Manuale di Ortopedia e Traumatologia, 2nd ed.; Elsevier: Amsterdam,

7. The Netherlands, 2012, Fitzgerald, R.; Kaufer, H.; Malkani, A.L. Trattato di Ortopedia e Traumatologia; Verduci: Woodbridge, ON, Canada, 2004

8. Harila V, Valkama M, Sato K, Tolleson S: Occlusal asymmetries in children with congenital hip dislocation. Eur J Orthod, 2012; 34: 307-11

9. Horak F, MacPherson JM. Postural orientation and equilibrium. In: Rowell LB, Shepherd JT, editors. Handbook of physiology - section 12. Exercise: regulation and integration of multiple systems. New York: Oxford University Press; 1996. p. 255-92

10. Ikemitsu H, Zeze R, Yuasa K, Izumi K: The relationship between jaw deformity and scoliosis. Journal Oral Radiology, 2006; 22: 14-17

11. Lippold C, van den Bos L, Hohoff A et al: Interdisciplinary study of orthopedic and orthodontic findings in pre-school infants. J Orofac Orthop, 2003; 64: 330-40

12. Lopatienė K, Šidlauskas A, Vasiliauskas A, Čečytè L, Švalkauskienė V, Šidlauskas M. Relationship between malocclusion, soft tissue profile, and pharyngeal airways: A cephalometric study. Medicina (Kaunas). 2016;52(5):307-314. doi: 10.1016/j.medici.2016.09.005. Epub 2016 Oct 11. PMID: 27816426

13. MacPherson JM, Horak FB. Posture. In: Kandel ER, Schwartz JH, Jessell TM, Siegelbaum SA, Hudspeth AJ, editors. Principles of neural science. New York: McGraw Hill; 2013. p. 935-59

14. McNeill C. Ciência e prática da oclusão. São Paulo: Quintessence, 2000

15. Park, J.H., Kim, H., Yang, H.S., \& Kim, K.S. (2014). The analysis of intranasal anatomic variations of Korean patients with malocclusion. Journal of The Anatomical Society of India, 63. Pages S6-S11 
16. Pérez LJ, Gómez S, Llano E, Rivera WA. Postura craneocervical em pacientes infantiles después de la terapia com mentonera. Un studio piloto. Revista Facultad de Odontología Universidad de Antioquia. 2009 Primer semestre;20(2)

17. Perillo L, Femminella B, Farronato D, Bacceti T, Contardo L, Perinetti G. Do malocclusion and Helkimo Index $\geq 5$ correlate with body posture? Journal of Oral Rehabilitation. 2011; 38:242-52

18. Perinetti G, Contardo L, Silvestrini-Biavati A, Perdoni L, Castaldo A. Dental malocclusion and body posture in young subjects: A multiple regression study. Clinics. 2010;65(7):689-95

19. Rizo AMH, Cabello MA, Pozo FP, Carrasco AL. La postura del segmento cráneo-cervical y su relación con la oclusión dental y la aplicación de ortodoncia: estudio de revisión. Osteopatía Cientifica. 2010; 05:89-96

20. Segatto E, Lippold C, Végh A: Craniofacial features of children with spinal deformities. BMC Musculoskelet Disorders, 2008; 9: 169-79

21. Silvestrini-Biavati A, Migliorati M, Demarziani E, Tecco S, Silvestrini-Biavati P, Polimeni A, Saccucci M. Clinical association between teeth malocclusions, wrong posture and ocular convergence disorders: an epidemiological investigation on primary school children. BMC Pediatrics. 2013; 13:12

22. Sinko K, Grohs JG, Millesi-Schobel G et al: Dysgnathia, orthognathic surgery and spinal posture. Int J Oral Maxillofac Surg, 2006; 35(4): $312-17$

23. Woollacott M. Shumway-Cook A. Williams H (1989) The development of posture and balance control. In: Woollacott MH. Shumway-Cook A (eds) Development of posture and gait across the life span. University of South Carolina Press. Columbia. pp 77-96

24. Yogi H, Alves LAC, Guedes R, Ciamponi AL. Determinant factors of malocclusion in children and adolescents with cerebral palsy. Am J Orthod Dentofacial Orthop. 2018 Sep;154(3):405-411. doi: 10.1016/j.ajodo.2017.11.042. PMID: 30173844 